\title{
Emerging Roles of Anti-Müllerian Hormone in Hypothalamic-Pituitary Function
}

\author{
Anne-Laure Barbotin ${ }^{\mathrm{a}, \mathrm{b}}$ Maëliss Peigné ${ }^{\mathrm{a}, \mathrm{c}}$ Samuel Andrew Malone ${ }^{\mathrm{a}}$ Paolo Giacobini $^{\mathrm{a}}$ \\ aUniversité de Lille, Inserm, CHU Lille, UMR-S 1172, Laboratoire du Développement et Plasticité du Cerveau \\ Neuroendocrine, Centre de Recherche Jean-Pierre Aubert, Lille, France; ${ }^{b}$ Institut de Biologie de la \\ Reproduction-Spermiologie-CECOS, CHU de Lille, Lille, France; ' $A P-H P$, Unité de Médecine de la Reproduction, \\ Service de Gynécologie-Obstétrique, Hôpital Bichat-Claude Bernard, Paris, France
}

\section{Keywords}

Anti-Müllerian hormone - Hypothalamic-pituitary function . Polycystic ovary syndrome

\begin{abstract}
Since its initial discovery in the 1940s, research into the physiological actions of anti-Müllerian hormone (AMH), from its eponymous role in male developmental biology to its routine clinical use in female reproductive health, has undergone a paradigm shifting change. With several exciting studies recently reporting hitherto unforeseen $\mathrm{AMH}$ actions at all levels in the hypogonadal-pituitary-gonadal axis, the importance of this hormone for both hypothalamic and pituitary reproductive control is finding increasing support and significance. In this review, we will briefly summarize what is known about the traditional roles and biology of AMH and how this could be integrated with new findings of AMH actions at the level of the hypothalamic-pituitary axis. We also synthesize the important findings from these new studies and discuss their potential impact and significance to our understanding of one of the most common reproductive disorders currently affecting women, polycystic ovary syndrome.

(c) 2019 The Author(s)

Published by S. Karger AG, Basel
\end{abstract}

\section{KARGER}

E-Mail karger@karger.com www.karger.com/nen

Karge (c) 2019 The Author(s) Published by S. Karger AG, Basel Open access

This article is licensed under the Creative Commons AttributionNonCommercial-NoDerivatives 4.0 International License (CC BY NC-ND) (http://www.karger.com/Services/OpenAccessLicense). Usage and distribution for commercial purposes as well as any distribution of modified material requires written permission.

\section{Introduction}

Anti-Müllerian hormone $(\mathrm{AMH})$ is a homodimeric glycoprotein belonging to the transforming growth factor (TGF)- $\beta$ family [1] and was initially identified for its role in regression of the Müllerian ducts in male embryos [2]. Prof. Jost [2] found that the Müllerian ducts of the rabbit would independently differentiate into the female reproductive system (i.e., the uterus, the fallopian tubes, and the upper two thirds of the vagina) in the absence of testicular secretions. Following gonadectomy of sexually undifferentiated rabbits, Jost [2] grafted either ovarian or testicular tissue in rabbits and witnessed the subsequent correct development of either female or male genitalia, respectively. The paradigm-shifting experiment came when, following gonadectomy, he implanted a testosterone proprionate crystal alone, noting that while the wolffian ducts were stimulated to develop, there was no regression of the Müllerian ducts - highlighting that a testicular factor other than testosterone was responsible for gonadal differentiation. Jost and Jost [3] called this factor "hormone in-

Samuel Andrew Malone and Paolo Giacobini contributed equally to this review.
Paolo Giacobini

Laboratoire du Développement et Plasticité du Cerveau Neuroendocrine Centre de Recherche Jean-Pierre Aubert, 1 Place de Verdun FR-59045 Lille Cedex (France)

E-Mail paolo.giacobini@inserm.fr 
hibitrice" or "inhibiteur Müllerian," and today it is better known as AMH or Müllerian-inhibiting substance (MIS).

The $A M H$ gene was first sequenced and cloned in mammals in 1986 [1, 4]. It is located on human chromosome 19 and is extremely well conserved through evolution, being characterized in almost all mammals [5-8], chickens [9], reptiles [10], marsupials [8], zebrafish [11], and amphibians [12]. It is comprised of 5 exons, with the highest degree of homogeneity being observed within exons $2-5$.

$\mathrm{AMH}$ is a glycoprotein found in the blood, suggesting that it has a hormonal function. The primary sources of production, identified so far, are the Sertoli cells of the testes and the granulosa cells of the ovaries in postnatal animals. However, expression of AMH and its exclusive binding receptor $\mathrm{AMH}$ receptor 2 (AMHR2) has also been detected in the prostate, lungs [13-15], and several other organs, including the brain and the pituitary [1620], suggesting that the biological effects of $\mathrm{AMH}$ are much broader than initially thought.

In the present review, we will briefly summarize previous studies describing the "canonical" functions of AMH in gonadal function and highlight our current understanding of emerging neuroendocrine actions of AMH in regulation of fertility in physiological and pathological conditions.

\section{AMH: from Gene to Protein}

The $A M H$ gene encodes a pre-proprotein of 560 amino acids in humans. $\mathrm{AMH}$ is synthesized as a homodimeric glycoprotein precursor of $140 \mathrm{kDa}$ (composed of 2 monomers of $70 \mathrm{kDa}$, stabilized by disulfide bridges), which undergoes proteolytic cleavage at monobasic sites to become biologically active [21-23]. $\mathrm{AMH}_{\mathrm{N}, \mathrm{C}}$ (a noncovalently associated $110-\mathrm{kDa} \mathrm{N}$-terminal dimer with a 25 $\mathrm{kDa} \mathrm{C}$ terminal dimer) represents the cleaved biologically active form, whereas uncleaved AMH (proAMH) is well described as biologically inactive [24-26]. Like many molecules of the TGF- $\beta$ superfamily, AMH must therefore undergo proteolytic cleavage into $2 \mathrm{~N}$ and $\mathrm{C}$ terminal dimers to acquire its biological function. Cleavage of $\mathrm{AMH}$ gives rise to a $110-\mathrm{kDa} \mathrm{N}$-terminal homodimer formed by two $57-\mathrm{kDa}$ subunits and a $25-\mathrm{kDa}$ active $\mathrm{C}$ homodimer composed of 2 identical $12.5-\mathrm{kDa}$ subunits. The noncovalent complex and prohormone are the 2 forms predominantly found in the blood of humans [25, 27]. It has been shown that the $\mathrm{N}$-terminal portion of the protein, despite having no intrinsic activity, has the role of amplifying the activity of the C-terminus, with only the

Emerging Roles of AMH in

Hypothalamic-Pituitary Function biologically active $\mathrm{C}$-terminus region required to cause regression of the Müllerian ducts [28].

As determined experimentally in vitro, recombinant AMH can be cleaved by plasmin [29]. However, in vivo, the enzymes capable of cleaving AMH remain largely unknown. Although the site of cleavage to form the bioactive AMH is currently unknown, subtilisin/kexin-like proprotein convertases are thought to be responsible for $\mathrm{AMH}$ cleavage and studies have shown that furin and proprotein convertase subtilisin/kexin type 5 (PCSK5), 2 such endoproteases, are coexpressed with $\mathrm{AMH}$ in embryonic rat testes [30]. Additionally, only PCSK5 is capable of cleaving this hormone after cotransfection into mammalian cells. It is also noteworthy that these convertases have been shown to be expressed by a high number of tissues and cells [31] and notably by neurons [32-34].

As a member of the TGF- $\beta$ family, AMH signals through a heterodimeric complex of transmembrane serine-threonine kinase receptors. AMH has been shown to bind exclusively to one type II receptor, i.e., AMHR2, while no other ligand has been shown to have effective binding to it [35]. AMHR2 has been shown to interact with the type 1 receptor serine/threonine kinases ACVR1 (activin A receptor type 1), BMPR1A (bone morphogenetic protein receptor type $1 \mathrm{~A}$ ), and BMPR1B (bone morphogenetic protein receptor type $1 B)[36,37]$. Finally, the complex canonically recruits SMAD $1 / 5 / 8$ proteins that are translocated to the nucleus and involved in regulation of gene expression [38, 39].

\section{Roles of AMH in Postnatal Gonads}

\section{Role of AMH in Ovarian Function}

In women, circulating AMH levels correlate well with ovarian reserve $[40,41]$, with the predictive power of $\mathrm{AMH}$ levels for ovarian reserve recently being widely adopted as the gold standard in primary health care systems [42] and as a useful co-predictor of stimulated ovarian response [41, 43].

$\mathrm{AMH}$ is produced by granulosa cells and, in women, a strong correlation exists between serum AMH levels and the number of small antral follicles between 2 and $9 \mathrm{~mm}$ as detected by ultrasound [43-45]. AMH is also a regulator of folliculogenesis as it inhibits the initial follicular recruitment from primordial follicles to primary follicles in mice $[46,47]$. This role has been confirmed by experiments in Amh knockout mice, which have statistically increased levels of primary and secondary follicles at 25 days and 4 months of age versus heterozygous and wild-type 
littermates. However, at 4 and 13 months, decreased numbers of primordial follicles were observed in Amh-knockout mice, suggesting a premature exhaustion of ovarian reserve [48]. The authors concluded that, although the number of initial primordial follicles available immediately following birth was independent of the presence of $\mathrm{AMH}$, it was an important factor in inhibiting follicular recruitment and thus $\mathrm{AMH}$ presence was essential for prolonging fecundity. AMH is already expressed in infantile ovaries in mammals [46, 49-54], and the findings of Garrel et al. [20] in 2016 raised the intriguing hypothesis that $\mathrm{AMH}$ could play a critical role in the female pituitary gonadotropic activity during the infantile period. This issue will be further discussed in "Emerging" Roles of AMH in Neuroendocrine Control of Reproduction.

In both rodent and human studies, it has been agreed that $\mathrm{AMH}$ secreted by primary and growing small antral follicles acts as a "brake" inhibiting further follicular recruitment and development. Further, FSH-dependent follicular maturation is inhibited in vitro by the addition of $\mathrm{AMH}$, indicating that $\mathrm{AMH}$ is important in attenuating follicular sensitivity to cyclical FSH action [55]. This is supported by a recent study that indicated that $\mathrm{AMH}$ levels parallel fluctuations in antral follicle count through the menstrual cycle [56].

In vitro experiments of cultured granulosa cells have indicated that exogenous AMH also decreases aromatase activity and the luteinizing hormone/choriogonadotropin receptor (LHCGR) number [57, 58]. Consistent with this, a negative correlation has been shown between $\mathrm{AMH}$ and estradiol levels in the follicular fluid of small antral follicles in humans $[59,60]$.

\section{Role of AMH in Testicular Function}

In boys, $\mathrm{AMH}$ is synthetized by Sertoli cells, and it is the first hormone secreted by differentiated Sertoli cells of the fetal testis triggering regression of the Müllerian ducts [61]. It has been demonstrated in humans that testicular AMH expression begins at 44 days postconception and that AMH levels in fetal testes were positively correlated with age [62].

Both Leydig and Sertoli cells of the testes express AMHR2, indicating a potential paracrine role in regulating male gonadal function [63]. Indeed, high doses of AMH result in decreased expression of some steroidogenic enzymes, mostly P450 17a-hydroxylase/C17-20 lyase (P450c17), and hence in reduced testosterone secretion in vitro [64] and in vivo [65]. Concomitantly, $\mathrm{AMH}$ also causes a decrease in LHR expression, which should further act to decrease testosterone secretion [64]. In line with these findings, in boys with nonpalpable testes, circulating $\mathrm{AMH}$ level determination can help to distinguish between cryptorchidism and anorchism, as well as in differentiating the dysgenetic causes of disorders of sexual development from those due to defective androgen synthesis or action [66]. Physiologically, AMH levels fall in boys at puberty with the increase in testosterone and the initiation of spermatogenesis [67]; however, it should be noted that this androgen-mediated decrease in AMH levels is restricted to postnatal life, as immature Sertoli cells lack expression of the androgen receptor $[68,69]$. Interestingly, AMH-deficient mice have circulating levels of testosterone within the normal range, suggesting that compensatory mechanisms may act to replace the interconnected feedback between the 2 hormones. Meanwhile, male mice with targeted mutations of AMHR2 develop Leydig cell hyperplasia, suggesting an inhibitory role of AMH on Leydig cell proliferation [70]. While secreting AMH into the peripheral blood circulation, Sertoli cells also secrete AMH into the seminiferous tubules, where it is present at a much higher concentration compared to the plasma $[71,72]$; however, the role of $\mathrm{AMH}$ in semen is currently unclear.

\section{"Emerging" Roles of AMH in Neuroendocrine Control of Reproduction}

\section{Role of AMH in the Hypothalamus}

In the adult brain, it has been shown that mature neurons express high levels of AMH receptors in both sexes [16-18].

In recent years, novel neuroendocrine actions of $\mathrm{AMH}$ have started to be elucidated. In 2016, Cimino et al. [19] uncovered that AMHR2 is expressed in a significant subset of hypothalamic gonadotropin-releasing hormone $(\mathrm{GnRH})$ neurons both in mice (Fig. 1) and in humans. Interestingly, AMHR2 is also broadly expressed in different brain areas and cell types involved in the central control of reproduction, including the organum vasculosum laminae terminalis (OVLT) of the hypothalamus and the median eminence [19]. Unpublished data from the same group have shown that neurons expressing nitric oxide synthase (nNOS) located in the OVLT also express AMHR2 (Fig. 1e). nNOS neurons distributed in the preoptic region at the median preoptic nucleus (MEPO) and in the OVLT, where neurons expressing nNOS and GnRH are located [73-75] and interact functionally [76, 77], are known to participate in the control of reproductive functions in mammals [78]. Future studies will be aimed at addressing the exact role of AMH on hypothalamic nNOS 
neurons and whether it could be involved in the nNOSmediated effects required for the onset of the LH surge induced by gonadal steroids in mice [75]. At the level of the median eminence, AMHR2 has been shown to be expressed by endothelial cells, by tanycytes, and by the majority of arcuate nucleus neurons (Fig. 1f-h). Interestingly, fenestrated endothelial cells and tanycytes are known to regulate $\mathrm{GnRH}$ secretion by interacting closely with GnRH terminals in the ME [79]. However, the role of $\mathrm{AMH}$ on these non-neuronal cell types is yet to be determined. The first functional study assessing the role of AMH on GnRH neuronal activity was published in 2016 and reported that approximately half of the GnRH neuronal population located in the hypothalamic preoptic area expresses AMHR2 and responds to exogenous AMH by increasing its neuronal activity and GnRH secretion, resulting in an increase in $\mathrm{LH}$ secretion equivalent to levels required to produce an ovulatory surge [19].

Electrophysiological experiments performed on slice cultures of preoptic areas from $G n R H<G F P>$ animals revealed that the action of exogenous $\mathrm{AMH}$ on neuronal activity is direct [19]; however, based on the wide expression of AMHR2 in hypothalamic regions, synergistic actions from other neuronal and non-neuronal cell types, ultimately resulting in increased $\mathrm{GnRH}$ secretion, cannot be ruled out.

Another point worth considering relates to the central effects of peripheral AMH and whether it could access the brain or not. In a recent study [80] it was shown that peripherally administered bioactive $\mathrm{AMH}_{\mathrm{C}}$ reaches the brain at the level of the ME and acts centrally by inducing $\mathrm{GnRH}$ neuronal activation, as shown by the increase in the number of GnRH neurons expressing c-fos. It has been previously shown that human blood contains pro$\mathrm{AMH}$ and $\mathrm{AMH}_{\mathrm{N}, \mathrm{C}}[25,81]$. In light of these considerations, at least 2 possible scenarios exist regarding how the peripheral AMH may result in the central activation of GnRH neurons: circulating $\mathrm{AMH}_{\mathrm{N}, \mathrm{C}}$ could (1) bind to endothelial cells of the ME, which express AMHR2, to induce the release of NO, which is known to powerfully control GnRH secretion and structural plasticity at the neurohemal junction [78], or (2) act directly on GnRH dendrites and terminals that extend outside the bloodbrain barrier at the OVLT [82] and in the ME, respectively, and/or modulate cytoskeletal remodeling in specialized ependymal glial cells called tanycytes to increase GnRH delivery to the pituitary [79] (Fig. 2). Indeed, the ME and the OVLT contain highly permeable, fenestrated endothelial cells that allow the free passage of molecules below $35 \mathrm{kDa}[83,84]$, such as bioactive AMH. However, whether prohormone convertases and furin, responsible for the cleavage to form the bioactive $\mathrm{AMH}$, are expressed by fenestrated vessels of circumventricular organs and whether circulating $\mathrm{AMH}_{\mathrm{N}, \mathrm{C}}$ undergoes further cleavage at these sites remain to be investigated.

\section{Role of AMH in the Pituitary}

Both AMHR2 transcripts and protein were found in immortalized mouse pituitary gonadotrope-derived cell lines (L $\beta$ T2) and in rat pituitaries $[20,85]$. Bédécarrats et al. [85] demonstrated that AMH stimulation of L $\beta$ T2 cells induces transcriptional activation of $L h b$ but not Fshb gene promoters. Interestingly, costimulation of L $\beta \mathrm{T} 2$ cells with $A M H$ and a GnRH agonist increased both the $F s h b$ and the $L h b$ gonadotropin gene promoter-driven luciferase activity [85]. This suggests that AMH enhances the effect of GnRH on the Fshb gene promoter and synergizes with the GnRH agonist to stimulate Lhb gene promoter activity. The group of Cohen-Tannoudji has further explored this issue in a set of subsequent studies [20, 86]. Using a combination of in vitro and in vivo approaches, these authors reported a sexually dimorphic expression of Amhr2 transcripts in the postnatal rat pituitary, with higher steady-state transcript levels in immature female rats than in males [20]. In addition, they provided compelling evidence that $\mathrm{AMH}$ increases the secretion of FSH in immature females. AMH was reported to upregulate FSH secretion and pituitary Fshb transcripts without affecting LH levels [20]. The same group also recently demonstrated that gene expression of both human and murine Amhr2 in gonadotrope cells is regulated by GnRH [86]. Indeed, using L $\beta T 2$ cells in a perifusion system, those authors showed that $\mathrm{GnRH}$ at a high pulse frequency increases $A m h r 2$ expression whereas lower frequencies are ineffective [86]. However, the physiological implication of Amhr2 upregulation by a high pulse frequency of GnRH remains to be understood.

In mammals, the infantile period is characterized by a transient elevation of the levels of the 2 gonadotropins shortly after birth [52, 87-90]. This phenomenon, known as minipuberty in humans, is the first of 3 activational periods that primes the HPG axis for puberty and adult fertility, setting in motion the growth of the first wave of ovarian follicles that will ovulate at puberty in females and the development of the testes in males [91]. Intriguingly, the amplitude of minipuberty (attested by FSH levels) varies tremendously depending on the gestational age at birth in both boys and girls, increasing up to 300 -fold in preterm female infants [92]. In rodents, a similar transient FSH peak has been reported at $~ 12-14$ days of post- 


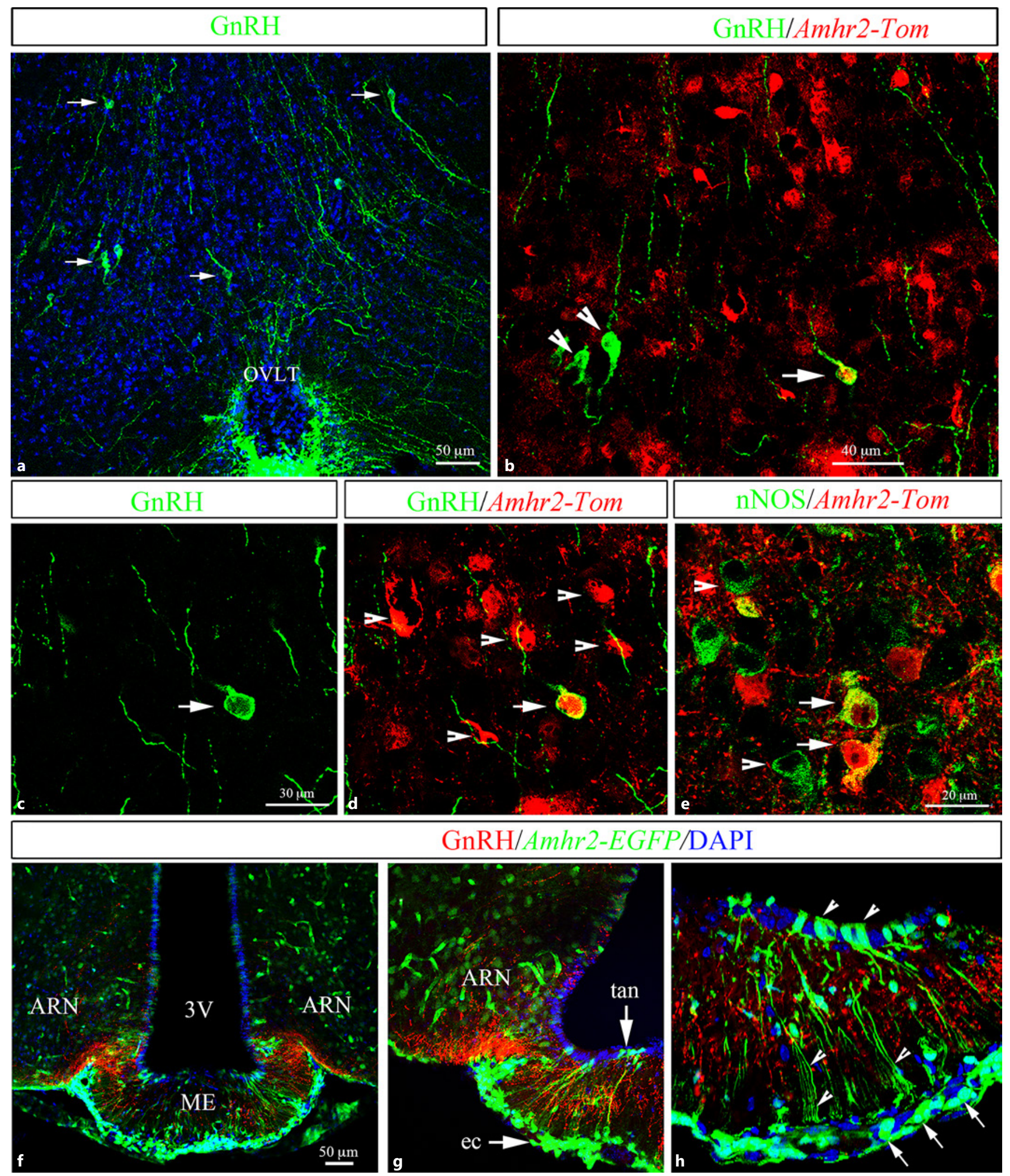


natal life $[93,94]$. Remarkably at the same time (PN14), $\mathrm{AMH}$ is downregulated in preantral/early antral follicles of the first waves [54]. Using cultures of infantile mice ovaries, those authors demonstrated the existence of a re- pressive action of FSH on AMH expression in preantral/ early antral follicles of the first follicular waves. Since treatment of infantile ovaries in organotypic cultures with $\mathrm{AMH}$ decreases FSH-mediated expression of

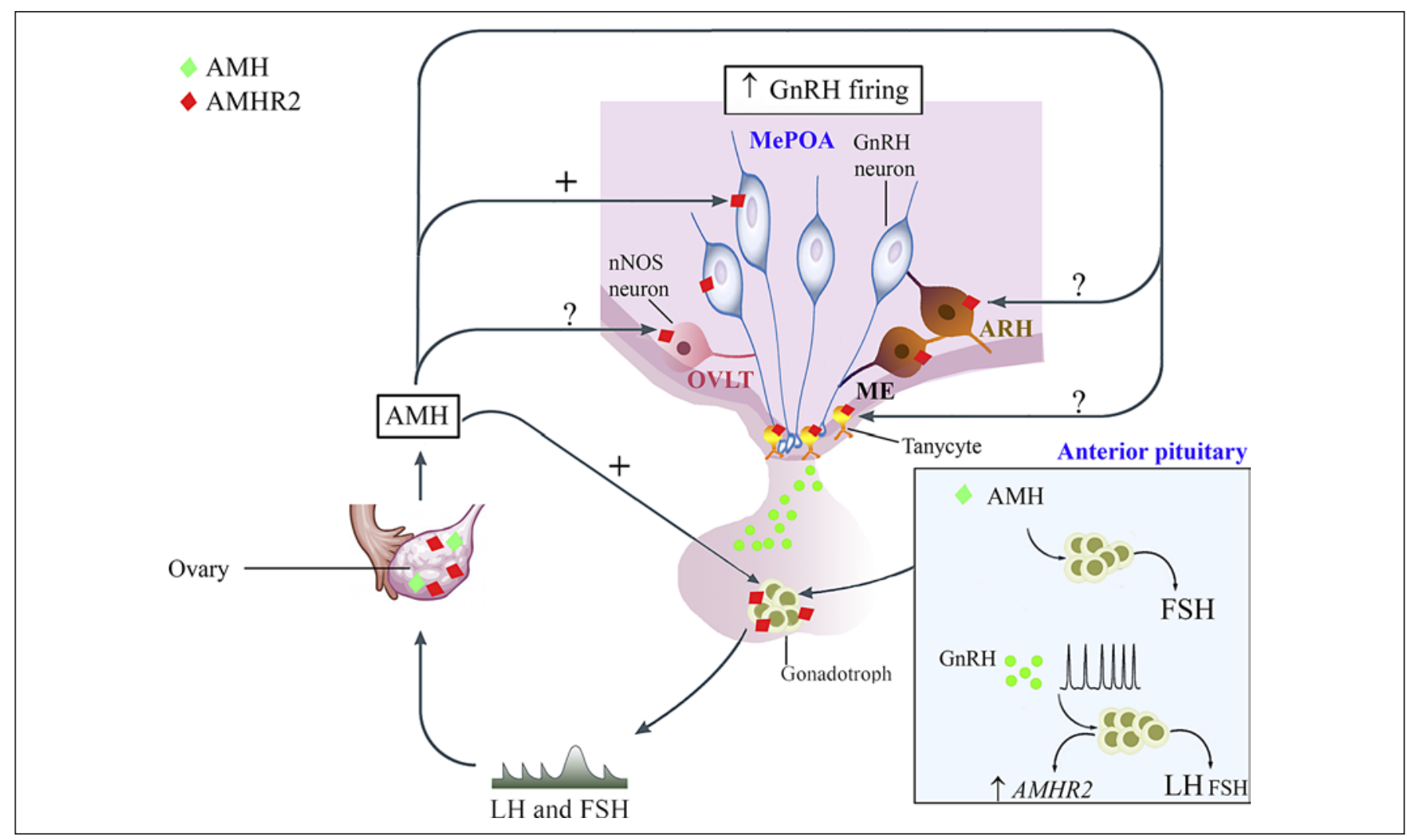

Fig. 2. Expression and function of AMH along the female hypothalamic-pituitary-gonadal axis in rodents. AMH is expressed in the ovaries from the infantile period until adulthood [see 46, 4953]. AMHR 2 is broadly expressed in different brain areas and cell types involved in the central control of reproduction, including the OVLT of the hypothalamus and the median eminence (ME) [19], although the AMH role in those cell populations has yet to be determined. GnRH neurons also express AMHR2 and respond to $A M H$ by increasing their neuronal activity and $\mathrm{GnRH}$ secretion. Amhr2 transcripts and AMHR2 protein were found in rodent pituitaries $[20,85]$. AMH has been reported to upregulate

Fig. 1. AMHR2 expression in adult female mouse hypothalamic cell populations controlling fertility. $\mathbf{a}-\mathbf{h}$ Representative coronal sections immunolabeled using antibodies against $\mathrm{GnRH}$, Tomato, GFP and nNOS. a GnRH immunoreactivity at the level of the OVLT. The arrows indicate GnRH cell bodies. b-d AMHR2 expression in Amhr2::Cre ${ }^{+/-}$; td Tomato ${ }^{\text {loxP/+ }}$ OVLT sections. Amhr2 is widely expressed in this region. A subpopulation of $\mathrm{GnRH}$ neurons (nearly 50\%) expresses Tomato (arrows). The arrowheads point to GnRH cell bodies, which are Amhr2 negative. e nNOS
FSH secretion and pituitary Fshb transcripts [20]. GnRH transactivates the human AMHR2 promoter in L $\beta$ T2 cells and Amhr2 expression has been shown to be differentially regulated by $\mathrm{GnRH}$ pulse frequency with an induction under high GnRH pulsatility [86]. Increasing frequencies of GnRH are also known to result in preferential secretion of LH. Finally, high levels of gonadotropin hormones during the infantile period have been recently proposed to prematurely sensitize the first follicular waves to the action of FSH [54], which lowers the Amh expression in these follicles, favoring Cyp19a1 aromatase expression and E2 production. immunoreactivity at the level of the OVLT. Several nNOS-expressing neurons in this region express Amhr2 (arrows). f-h Amhr2 expression was also analyzed in a Amhr2::Cre ${ }^{+/} ; \mathrm{LacZ} /$ EGFP reporter mouse line. Amhr2 was found in the arcuate nucleus (ARN) and in the median eminence (ME; arrows in $\mathbf{g}$ ), where $\mathrm{GnRH}$ terminals project (red staining). Amhr2-expressing cells were found in hypothalamic tanycytes (tan; arrowheads in $\mathbf{h}$ ) lining the third ventricle (3V) and endothelial cells (ec; arrows in h) [see also 19]. 


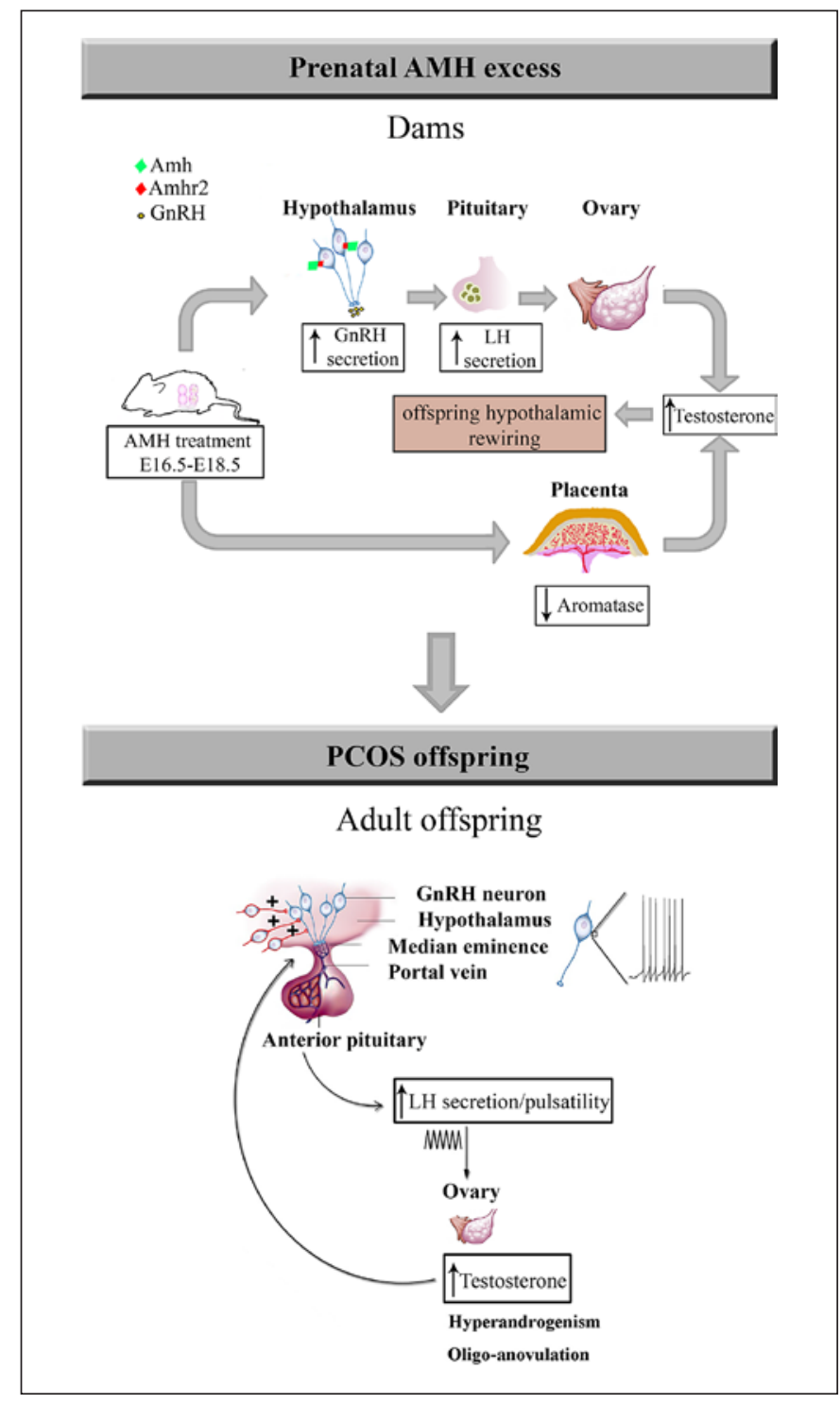

Fig. 3. AMH prenatal reprogramming of PCOS: potential prenatal and postnatal mechanisms. Pregnant women with PCOS have a 2 -fold increase in circulating AMH levels compared to pregnant women with normal fertility during the second trimester of gestation as well as at term $[80,121]$. In mice, prenatal exposure to elevated AMH levels leads to increased $\mathrm{GnRH} / \mathrm{LH}$ pulsatility in dams, driving gestational steroidogenesis and hyperandrogenism. The maternal LH excess (driven by AMH action in the maternal hypothalamus), alone or in combination with $\mathrm{AMH}$, engages placental deficits by inhibition of aromatase expression. This leads to an increase in testosterone bioavailability. The elevated levels of testosterone trigger a cascade of events in the offspring, which converge into altered hypothalamic wiring. In adult female PCOS offspring, the increase in excitatory input to $\mathrm{GnRH}$ drives a persistent rise in the $\mathrm{GnRH}$ neuronal firing activity. Finally, the constitutive hyperactivity of GnRH neurons stimulates ovarian androgen production, which appears to inhibit the negative feedback effects of estrogens and progesterone on pulsatile LH release, impairing folliculogenesis and ovulation and thus contributing to the vicious circle of PCOS [see also 80].
Cyp19a1 aromatase, the authors hypothesized that the negative action of FSH on AMH expression is necessary to alleviate the inhibitory action of AMH on FSH-dependent E2 biosynthesis in these growing follicles [54].

Altogether, these studies shed new light on the role of AMH in the control of the hypothalamic-pituitary function and regulation of fertility in physiological conditions during the infantile period and in adulthood (Fig. 2).

\section{AMH Relevance for Polycystic Ovary Syndrome}

\section{Functional Variation of AMH Pathway in Polycystic Ovary Syndrome}

Polycystic ovary syndrome (PCOS) is a complex reproductive endocrine disorder, affecting more than $10 \%$ of women worldwide and representing the primary cause of anovulatory infertility [95]. Furthermore, PCOS associates comorbidities including metabolic dysfunction and an increased risk of type 2 diabetes mellitus and cardiovascular disease $[96,97]$.

A recent international guideline for the assessment and management of PCOS announced in 2018 [98] promotes the use of the Rotterdam diagnostic criteria [99]. These criteria require the presence of at least 2 of the following 3 features of PCOS: oligo-anovulation, hyperandrogenism, and polycystic ovary morphology at ultrasound.

PCOS has long been considered mainly a gonadal pathology, but more recently accumulating evidence has started to shed light on the neuroendocrine impairments associated with the pathophysiology of this syndrome [100]. In women with PCOS, AMH serum levels are frequently found to be 2- to 3-fold higher than in women with healthy ovaries $[101,102]$. Moreover, the severity of the PCOS phenotype correlates with AMH production, which is higher in anovulatory than in ovulatory PCOS patients [103-105]. Interestingly, circulating AMH levels have been found to be significantly higher also in naturally hyperandrogenic female rhesus monkeys, which exhibit traits typical of women with PCOS [106].

Clinically observed correlations between enhanced basal levels of AMH and PCOS have led to a well-developed physiological role for AMH in follicular development [107].

In women with PCOS, a positive correlation between LH and AMH serum levels has been shown [108] independently of androgen and FSH levels [109]. In addition, several authors have shown that $\mathrm{LH}$ could stimulate AMH secretion and expression $[103,110]$. LH hypertonia is 
found in about $50 \%$ of women with PCOS, with a prevalence of up to $95 \%$ in metabolically healthy women with PCOS [111]. The high circulating LH levels reported in women with PCOS further exacerbate hyperandrogenism by stimulating thecal cell androgen production. The increase in LH frequency in these women could be attributed to a lack of negative feedback from progesterone as a result of hypothalamic prenatal androgenization [100, 112]. The elevated LH pulse frequency is also suggestive of an acceleration of the GnRH pulse frequency [113, 114]. Nevertheless, the origin of GnRH hypersecretion in women with PCOS is unknown, as is whether this alone could be sufficient to trigger the cascade of events leading to PCOS. As detailed above, a recent study showed that in rodent $\mathrm{AMH}$ induces $\mathrm{LH}$ secretion by stimulating GnRH neuronal activation and subsequent neuropeptide secretion [19]. These results raise the innovative hypothesis that $\mathrm{AMH}$, the circulating levels of which are abnormally elevated in PCOS patients with severe oligo-anovulation, might contribute significantly to the hormonal and gonadal alterations that are observed in women with PCOS and have an impact on fertility by centrally affecting GnRH neuronal excitability prenatally and/or postnatally.

\section{AMH and Neuroendocrine Origins of PCOS}

Familial clustering and twin studies have shown that PCOS has a strong heritable component [115]. Polymorphisms in both $A M H$ and $A M H R 2$ have been identified in women with PCOS [116-118]. However, the polymorphisms identified in the AMH signaling pathway and in other genes do not explain the frequency of the disease [119], suggesting that environmental and epigenetic mechanisms may play far greater roles in the onset of PCOS.

In women with PCOS, endocrine alterations, such as hormonal imbalances, during gestation may contribute to an increased risk of their offspring developing PCOS [120]. Prenatal exposure to androgens, testosterone (T) or dihydrotestosterone, have been reported to generate the closest PCOS-like phenotype in a variety of animal models [100]. This points to prenatal hyperandrogenism as one of the main triggers of the developmental programming of PCOS. Notably, 2 recent studies [80, 121] showed that pregnant women with PCOS have significantly higher circulating AMH levels (during the second trimester of gestation as well as at term) than pregnant women with normal fertility. This 2 -fold greater AMH level compared to controls adds AMH to the list of potential candidates in the prenatal programming of PCOS.
Piltonen et al. [121] also reported novel data on the correlation between gestational AMH and androgen levels in humans in late pregnancy in a time window sensitive to the trigger PCOS-like phenotype in offspring in animal models. Moreover, recent data also suggest a possible role for $\mathrm{AMH}$ in transgenerational PCOS pathogenesis, as high gestational AMH levels in mice result in a hyperandrogenic PCOS-like phenotype in adult female offspring [80] (Fig. 3).

Interestingly, prenatal $\mathrm{AMH}$ treatment leads to a significant 3 -fold $\mathrm{T}$ increase in the dams, which is likely responsible for rewiring of the fetal hypothalamic circuits (Fig. 3) to excessive excitatory inputs onto $\mathrm{GnRH}$ neurons and finally leads to neuroendocrine and reproductive defects in the offspring. However, whether T levels are also elevated in the amniotic liquid of the fetus remains to be assessed. AMH-dependent maternal androgenization is most likely the result of a dual action of AMH on the dams' physiology: (1) a central action exacerbating GnRH- and LH-driven ovarian steroidogenesis and (2) AMH-driven inhibition of aromatase expression in the placenta, which leads to an increase in T bioavailability [80]. In humans, AMH has been shown to modify the enzymatic activity of steroid hormone synthesis [122], and women with PCOS have been reported to have reduced placental aromatase activity and increased steroidogenic activity [101], giving support to the findings of the group of Giacobini also in humans. Most women with PCOS are hyperandrogenic during pregnancy [120, 123], yet the cause of this remains enigmatic. The work of Tata et al. [80] raises the intriguing hypothesis as to whether the origin of the gestational hyperandrogenism of women with PCOS lies in elevated AMH levels during pregnancy and inhibition of aromatase expression/activity, although it is not yet known whether a causal relationship between AMH and T exists during gestation in humans. Another important finding of this study relates to the fact that the AMH-dependent prenatal hyperandrogenism leads to a persistent GnRH neuronal hyperactivity in the adult offspring (Fig. 3). The novel proposal guiding this study is that PCOS could involve brain deregulation and that exacerbation of $\mathrm{GnRH}$ neuronal activity/secretion could be the basis for neuroendocrine anomalies that accompany the gonadal disturbances in the syndrome. Indeed, prenatal co-treatment of $\mathrm{AMH}$ with a $\mathrm{GnRH}$ antagonist prevented the appearance of PCOS-like neuroendocrine traits in the offspring, suggesting a critical role for $\mathrm{GnRH}$ in prenatal programming of the disease [80]. Even more strikingly, the same authors provided compelling evidence that intermittent de- 
livery of a GnRH antagonist to adult prenatal AMH-treated mice corrected their neuroendocrine and reproductive alterations. Given the fact that GnRH antagonists are frequently used in the clinic, pharmacological antagonism aimed at tempering GnRH-LH secretion is an attractive therapeutic strategy to restore ovulation and fertility in individuals with PCOS characterized by high LH levels.

\section{Conclusion}

Since its discovery, great strides have been made that have allowed us to develop an appreciation of the role of $\mathrm{AMH}$ in both male and female gonadal function and how dysregulated AMH signaling is involved in infertility syndromes. While we now have a much broader understanding of and insight into disorders such as PCOS thanks to this enormous amount of work, we are still far from comprehending the true etiology of this syndrome, with genetic traits only partially able to sustain a fraction of the clinical cases. The recent work building on the discovery of AMH receptors outside of the gonads and their ability to regulate both gonadotropic cells of the anterior pituitary and the hypothalamus strongly suggests that AMH is a neuroendocrine regulator of fertility. Much work still needs to be done to elucidate the mode of action in the hypothalamus and the significance of its role in the pituitary, but these novel sites of action provide new insights into the pathophysiology of reproductive dysfunction and open further routes of investigations.

\section{Acknowledgement}

This study was supported by the European Research Council (ERC) under the Horizon 2020 research and innovation program of the European Union (ERC-2016-CoG to P.G.; grant agreement No. 725149/REPRODAMH) and by the Institut National de la Santé et de la Recherche Médicale (INSERM), France (grant No. U1172).

\section{Disclosure Statement}

The authors have nothing to disclose.

\section{References}

1 Cate RL, Mattaliano RJ, Hession C, Tizard R, Farber NM, Cheung A, et al. Isolation of the bovine and human genes for Müllerian inhibiting substance and expression of the human gene in animal cells. Cell. 1986 Jun;45(5):68598.

2 Jost A. The age factor in the castration of male rabbit fetuses. Proc Soc Exp Biol Med. 1947 Nov;66(2):302-3.

3 Jost A, Jost CA. Problems of fetal endocrinology: the gonadal and hypophyseal hormones. Recent Prog Horm Res. 1953;8:379418.

4 Picard JY, Benarous R, Guerrier D, Josso N, Kahn A. Cloning and expression of cDNA for anti-müllerian hormone. Proc Natl Acad Sci USA. 1986 Aug;83(15):5464-8.

5 Münsterberg A, Lovell-Badge R. Expression of the mouse anti-müllerian hormone gene suggests a role in both male and female sexual differentiation. Development. 1991 Oct; 113(2):613-24

6 Haqq C, Lee MM, Tizard R, Wysk M, DeMarinis J, Donahoe PK, et al. Isolation of the rat gene for Mullerian inhibiting substance. Genomics. 1992 Apr;12(4):665-9.

7 Lahbib-Mansais Y, Barbosa A, Yerle M, Parma P, Milan D, Pailhoux E, et al. Mapping in pig of genes involved in sexual differentiation: AMH, WT1, FTZF1, SOX2, SOX9, AHC, and placental and embryonic CYP19. Cytogenet Cell Genet. 1997;76(12):109-14.
8 Pask AJ, Whitworth DJ, Mao CA, Wei KJ, Sankovic N, Graves JA, et al. Marsupial antiMullerian hormone gene structure, regulatory elements, and expression. Biol Reprod. 2004 Jan;70(1):160-7.

9 Oreal E, Pieau C, Mattei MG, Josso N, Picard JY, Carré-Eusèbe D, et al. Early expression of $\mathrm{AMH}$ in chicken embryonic gonads precedes testicular SOX9 expression. Dev Dyn. 1998 Aug;212(4):522-32.

10 Western PS, Harry JL, Graves JA, Sinclair AH. Temperature-dependent sex determination in the American alligator: AMH precedes SOX9 expression. Dev Dyn. 1999 Dec;216(4-5): 411-9.

11 Schulz RW, Bogerd J, Male R, Ball J, Fenske $\mathrm{M}$, Olsen LC, et al. Estrogen-induced alterations in amh and dmrtl expression signal for disruption in male sexual development in the zebrafish. Environ Sci Technol. 2007 Sep; 41(17):6305-10.

12 Al-Asaad I, Chardard D, di Clemente N, Picard JY, Dumond H, Chesnel A, et al. Müllerian inhibiting substance in the caudate amphibian Pleurodeles waltl. Endocrinology. 2013 Oct;154(10):3931-6.

13 Gustafson ML, Lee MM, Asmundson L, MacLaughlin DT, Donahoe PK. Müllerian inhibiting substance in the diagnosis and management of intersex and gonadal abnormalities. J Pediatr Surg. 1993 Mar;28(3): $439-44$
14 Long WQ, Ranchin V, Pautier P, Belville C, Denizot P, Cailla H, et al. Detection of minimal levels of serum anti-Müllerian hormone during follow-up of patients with ovarian granulosa cell tumor by means of a highly sensitive enzyme-linked immunosorbent assay. J Clin Endocrinol Metab. 2000 Feb;85(2):540-4.

15 La Marca A, De Leo V, Giulini S, Orvieto R, Malmusi S, Giannella L, et al. Anti-Mullerian hormone in premenopausal women and after spontaneous or surgically induced menopause. J Soc Gynecol Investig. 2005 Oct;12(7): 545-8.

16 Wang PY, Koishi K, McGeachie AB, Kimber M, Maclaughlin DT, Donahoe PK, et al. Mullerian inhibiting substance acts as a motor neuron survival factor in vitro. Proc Nat Acad Sci USA. 2005 Nov; 102(45):16421-5.

17 Wang PY, Protheroe A, Clarkson AN, Imhoff F, Koishi K, McLennan IS. Müllerian inhibiting substance contributes to sex-linked biases in the brain and behavior. Proc Natl Acad Sci USA. 2009 Apr; 106(17):7203-8.

18 Lebeurrier N, Launay S, Macrez R, Maubert E, Legros H, Leclerc A, et al. Anti-Mullerianhormone-dependent regulation of the brain serine-protease inhibitor neuroserpin. J Cell Sci. 2008 Oct;121(Pt 20):3357-65.

19 Cimino I, Casoni F, Liu X, Messina A, Parkash $\mathrm{J}$, Jamin SP, et al. Novel role for anti-Müllerian hormone in the regulation of GnRH neuron excitability and hormone secretion. Nat Commun. 2016 Jan;7(1):10055. 
20 Garrel G, Racine C, L'Hôte D, Denoyelle C, Guigon CJ, di Clemente N, et al. Anti-Müllerian hormone: a new actor of sexual dimorphism in pituitary gonadotrope activity before puberty. Sci Rep. 2016 Mar;6(1): 23790.

21 Picard JY, Josso N. Anti-Müllerian hormone: estimation of molecular weight by gel filtration. Biomedicine. 1976 Jun;25(4): 147-50.

22 Picard JY, Josso N. Purification of testicular anti-Müllerian hormone allowing direct visualization of the pure glycoprotein and determination of yield and purification factor. $\mathrm{Mol}$ Cell Endocrinol. 1984 Jan;34(1):23-9.

23 di Clemente N, Ghaffari S, Pepinsky RB, Pieau C, Josso N, Cate RL, et al. A quantitative and interspecific test for biological activity of anti-müllerian hormone: the fetal ovary aromatase assay. Development. 1992 Mar; 114(3):721-7.

24 di Clemente N, Jamin SP, Lugovskoy A, Carmillo P, Ehrenfels C, Picard JY, et al. Processing of anti-mullerian hormone regulates receptor activation by a mechanism distinct from TGF-beta. Mol Endocrinol. 2010 Nov; 24(11):2193-206.

25 Pankhurst MW, McLennan IS. Human blood contains both the uncleaved precursor of anti-Mullerian hormone and a complex of the $\mathrm{NH} 2$ - and $\mathrm{COOH}$-terminal peptides. Am J Physiol Endocrinol Metab. 2013 Nov; 305(10):E1241-7.

26 MacLaughlin DT, Hudson PL, Graciano AL, Kenneally MK, Ragin RC, Manganaro TF, et al. Mullerian duct regression and antiproliferative bioactivities of mullerian inhibiting substance reside in its carboxy-terminal domain. Endocrinology. 1992 Jul;131(1):291-6.

27 McLennan IS, Pankhurst MW. Anti-Müllerian hormone is a gonadal cytokine with two circulating forms and cryptic actions. J Endocrinol. 2015 Sep;226(3):R45-57.

28 Wilson CA, di Clemente N, Ehrenfels C, Pepinsky RB, Josso N, Vigier B, et al. Mullerian inhibiting substance requires its $\mathrm{N}$-terminal domain for maintenance of biological activity, a novel finding within the transforming growth factor-beta superfamily. Mol Endocrinol. 1993 Feb;7(2):247-57.

29 Pepinsky RB, Sinclair LK, Chow EP, Mattaliano RJ, Manganaro TF, Donahoe PK, et al. Proteolytic processing of mullerian inhibiting substance produces a transforming growth factor-beta-like fragment. J Biol Chem. 1988 Dec;263(35):18961-4.

30 Nachtigal MW, Ingraham HA. Bioactivation of Müllerian inhibiting substance during gonadal development by a kex2/subtilisin-like endoprotease. Proc Natl Acad Sci USA. 1996 Jul;93(15):7711-6.

31 Stadler C, Rexhepaj E, Singan VR, Murphy RF, Pepperkok R, Uhlén M, et al. Immunofluorescence and fluorescent-protein tagging show high correlation for protein localization in mammalian cells. Nat Methods. 2013 Apr; 10(4):315-23.
32 Cain BM, Connolly K, Blum A, Vishnuvardhan D, Marchand JE, Beinfeld MC. Distribution and colocalization of cholecystokinin with the prohormone convertase enzymes PC1, PC2, and PC5 in rat brain. J Comp Neurol. 2003 Dec;467(3):307-25.

33 Villeneuve P, Seidah NG, Beaudet A. Immunohistochemical evidence for the implication of $\mathrm{PC} 1$ in the processing of proneurotensin in rat brain. Neuroreport. 2000 Nov;11(16): 3443-7.

34 Winsky-Sommerer R, Benjannet S, Rovère C, Barbero P, Seidah NG, Epelbaum J, et al. Regional and cellular localization of the neuroendocrine prohormone convertases $\mathrm{PC} 1$ and PC2 in the rat central nervous system. J Comp Neurol. 2000 Aug;424(3):439-60.

35 Mishina Y, Rey R, Finegold MJ, Matzuk MM, Josso N, Cate RL, et al. Genetic analysis of the Müllerian-inhibiting substance signal transduction pathway in mammalian sexual differentiation. Genes Dev. 1996 Oct;10(20):257787.

36 Baarends WM, van Helmond MJ, Post M, van der Schoot PJ, Hoogerbrugge JW, de Winter JP, et al. A novel member of the transmembrane serine/threonine kinase receptor family is specifically expressed in the gonads and in mesenchymal cells adjacent to the müllerian duct. Development. 1994 Jan; 120(1):189-97.

37 di Clemente N, Wilson C, Faure E, Boussin L, Carmillo P, Tizard R, et al. Cloning, expression, and alternative splicing of the receptor for anti-Müllerian hormone. Mol Endocrinol. 1994 Aug;8(8):1006-20.

38 Josso N, Clemente N. Transduction pathway of anti-Müllerian hormone, a sex-specific member of the TGF-beta family. Trends Endocrinol Metab. 2003 Mar;14(2):91-7.

39 Shi Y, Massagué J. Mechanisms of TGF-beta signaling from cell membrane to the nucleus. Cell. 2003 Jun;113(6):685-700.

40 van Rooij IA, Broekmans FJ, te Velde ER, Fauser BC, Bancsi LF, de Jong FH, et al. Serum anti-Müllerian hormone levels: a novel measure of ovarian reserve. Hum Reprod. 2002 Dec;17(12):3065-71

41 Peñarrubia J, Fábregues F, Manau D, Creus M, Casals G, Casamitjana R, et al. Basal and stimulation day 5 anti-Mullerian hormone serum concentrations as predictors of ovarian response and pregnancy in assisted reproductive technology cycles stimulated with gonadotropin-releasing hormone agonist-gonadotropin treatment. Hum Reprod. 2005 Apr; 20(4):915-22.

42 Grynnerup AG, Lindhard A, Sørensen S. The role of anti-Müllerian hormone in female fertility and infertility - an overview. Acta Obstet Gynecol Scand. 2012 Nov;91(11):125260.

43 La Marca A, Sighinolfi G, Radi D, Argento C, Baraldi E, Artenisio AC, et al. Anti-Mullerian hormone (AMH) as a predictive marker in assisted reproductive technology (ART). Hum Reprod Update. 2010 Mar-Apr;16(2):113-30.
44 Dewailly D, Gronier H, Poncelet E, Robin G, Leroy M, Pigny P, et al. Diagnosis of polycystic ovary syndrome (PCOS): revisiting the threshold values of follicle count on ultrasound and of the serum AMH level for the definition of polycystic ovaries. Hum Reprod. 2011 Nov;26(11):3123-9.

45 Dewailly D, Andersen CY, Balen A, Broekmans F, Dilaver N, Fanchin R, et al. The physiology and clinical utility of anti-Mullerian hormone in women. Hum Reprod Update. 2014 May-Jun;20(3):370-85.

46 La Marca A, Sighinolfi G, Radi D, Argento C, Baraldi E, Artenisio AC, et al. Anti-Mullerian hormone (AMH) as a predictive marker in assisted reproductive technology (ART). Hum Reprod Update. 2010 Mar-Apr;16(2):113-30.

47 Carlsson IB, Scott JE, Visser JA, Ritvos O, Themmen AP, Hovatta O. Anti-Müllerian hormone inhibits initiation of growth of human primordial ovarian follicles in vitro. Hum Reprod. 2006 Sep;21(9):2223-7.

48 Durlinger AL, Kramer P, Karels B, de Jong FH, Uilenbroek JT, Grootegoed JA, et al. Control of primordial follicle recruitment by antiMüllerian hormone in the mouse ovary. Endocrinology. 1999 Dec;140(12):5789-96.

49 Baarends WM, Uilenbroek JT, Kramer P, Hoogerbrugge JW, van Leeuwen EC, Themmen $\mathrm{AP}$, et al. Anti-müllerian hormone and antimüllerian hormone type II receptor messenger ribonucleic acid expression in rat ovaries during postnatal development, the estrous cycle, and gonadotropin-induced follicle growth. Endocrinology. 1995 Nov;136(11):4951-62.

50 Mazaud S, Guigon CJ, Lozach A, Coudouel N, Forest MG, Coffigny $\mathrm{H}$, et al. Establishment of the reproductive function and transient fertility of female rats lacking primordial follicle stock after fetal gamma-irradiation. Endocrinology. 2002 Dec;143(12):4775-87.

51 Hagen CP, Aksglaede L, Sørensen K, Main KM, Boas M, Cleemann L, et al. Serum levels of anti-Müllerian hormone as a marker of ovarian function in 926 healthy females from birth to adulthood and in 172 Turner syndrome patients. J Clin Endocrinol Metab. 2010 Nov;95(11):5003-10.

52 Kuiri-Hänninen T, Kallio S, Seuri R, Tyrväinen E, Liakka A, Tapanainen J, et al. Postnatal developmental changes in the pituitary-ovarian axis in preterm and term infant girls. J Clin Endocrinol Metab. 2011 Nov;96(11):3432-9.

53 Torres-Rovira L, Succu S, Pasciu V, Manca ME, Gonzalez-Bulnes A, Leoni GG, et al. Postnatal pituitary and follicular activation: a revisited hypothesis in a sheep model. Reproduction. 2016 Mar;151(3):215-25.

54 Devillers M, Petit F, Cluzet V, François CM, Giton F, Garrel G, et al. FSH inhibits AMH to support ovarian estradiol synthesis in infantile mice. J Endocrinol. 2018 Nov;pii:JOE-18-0313.R1.

55 Durlinger AL, Gruijters MJ, Kramer P, Karels B, Kumar TR, Matzuk MM, et al. Anti-Müllerian hormone attenuates the effects of FSH on follicle development in the mouse ovary. Endocrinology. 2001 Nov;142(11):4891-9.
Emerging Roles of AMH in

Hypothalamic-Pituitary Function
Neuroendocrinology 2019;109:218-229 DOI: $10.1159 / 000500689$ 
56 Depmann M, van Disseldorp J, Broer SL, Eijkemans MJ, Laven JS, Visser JA, et al. Fluctuations in anti-Müllerian hormone levels throughout the menstrual cycle parallel fluctuations in the antral follicle count: a cohort study. Acta Obstet Gynecol Scand. 2016 Jul; 95(7):820-8.

57 Grossman MP, Nakajima ST, Fallat ME, Siow Y. Müllerian-inhibiting substance inhibits cytochrome P450 aromatase activity in human granulosa lutein cell culture. Fertil Steril. 2008 May;89(5 Suppl):1364-70.

58 Chang HM, Klausen C, Leung PC. Antimüllerian hormone inhibits follicle-stimulating hormone-induced adenylyl cyclase activation, aromatase expression, and estradiol production in human granulosa-lutein cells. Fertil Steril. 2013 Aug;100(2):585-92.e1.

59 Andersen CY, Byskov AG. Estradiol and regulation of anti-Müllerian hormone, inhibin$\mathrm{A}$, and inhibin-B secretion: analysis of small antral and preovulatory human follicles' fluid. J Clin Endocrinol Metab. 2006 Oct;91(10): 4064-9.

60 Dumesic DA, Lesnick TG, Stassart JP, Ball GD, Wong A, Abbott DH. Intrafollicular antimüllerian hormone levels predict follicle responsiveness to follicle-stimulating hormone (FSH) in normoandrogenic ovulatory women undergoing gonadotropin releasing-hormone analog/recombinant human FSH therapy for in vitro fertilization and embryo transfer. Fertil Steril. 2009 Jul;92(1):217-21.

61 Tran D, Muesy-Dessole N, Josso N. AntiMüllerian hormone is a functional marker of foetal Sertoli cells. Nature. 1977 Sep; 269(5627):411-2.

62 Mamsen LS, Ernst EH, Borup R, Larsen A, Olesen RH, Ernst E, et al. Temporal expression pattern of genes during the period of sex differentiation in human embryonic gonads. Sci Rep. 2017 Nov;7(1):15961.

63 Lee MM, Seah CC, Masiakos PT, Sottas CM, Preffer FI, Donahoe PK, et al. Müllerian-inhibiting substance type II receptor expression and function in purified rat Leydig cells. Endocrinology. 1999 Jun;140(6):2819-27.

64 Racine C, Rey R, Forest MG, Louis F, Ferré A, Huhtaniemi I, et al. Receptors for anti-müllerian hormone on Leydig cells are responsible for its effects on steroidogenesis and cell differentiation. Proc Natl Acad Sci USA. 1998 Jan;95(2):594-9.

65 Trbovich AM, Sluss PM, Laurich VM, O'Neill FH, MacLaughlin DT, Donahoe PK, et al. Müllerian Inhibiting Substance lowers testosterone in luteinizing hormone-stimulated rodents. Proc Natl Acad Sci USA. 2001 Mar; 98(6):3393-7.

66 Weintraub A, Eldar-Geva T. Anti-Mullerian Hormone (AMH) Determinations in the Pediatric and Adolescent Endocrine Practice. Pediatr Endocrinol Rev. 2017 Jun;14(4):364-70.

67 Rey R. Anti-Müllerian hormone in disorders of sex determination and differentiation. Arq Bras Endocrinol Metabol. 2005 Feb;49(1):2636.
68 Chemes HE, Rey RA, Nistal M, Regadera J, Musse M, González-Peramato P, et al. Physiological androgen insensitivity of the fetal, neonatal, and early infantile testis is explained by the ontogeny of the androgen receptor expression in Sertoli cells. J Clin Endocrinol Metab. 2008 Nov;93(11):4408-12.

69 Boukari K, Meduri G, Brailly-Tabard S, Guibourdenche J, Ciampi ML, Massin N, et al. Lack of androgen receptor expression in Sertoli cells accounts for the absence of anti-Mullerian hormone repression during early human testis development. J Clin Endocrinol Metab. 2009 May;94(5):1818-25.

70 Behringer RR, Finegold MJ, Cate RL. Müllerian-inhibiting substance function during mammalian sexual development. Cell. 1994 Nov;79(3):415-25.

71 Fallat ME, Siow Y, Belker AM, Boyd JK, Yoffe S, MacLaughlin DT. The presence of müllerian inhibiting substance in human seminal plasma. Hum Reprod. 1996 Oct;11(10):2165-9.

72 Fénichel P, Rey R, Poggioli S, Donzeau M, Chevallier D, Pointis G. Anti-Müllerian hormone as a seminal marker for spermatogenesis in non-obstructive azoospermia. Hum Reprod. 1999 Aug;14(8):2020-4.

73 Herbison AE, Simonian SX, Norris PJ, Emson PC. Relationship of neuronal nitric oxide synthase immunoreactivity to GnRH neurons in the ovariectomized and intact female rat. J Neuroendocrinol. 1996 Jan;8(1):73-82.

74 d'Anglemont de Tassigny X, Campagne C, Dehouck B, Leroy D, Holstein GR, Beauvillain JC, et al. Coupling of neuronal nitric oxide synthase to NMDA receptors via postsynaptic density-95 depends on estrogen and contributes to the central control of adult female reproduction. J Neurosci. 2007 Jun; 27(23):6103-14.

75 Hanchate NK, Parkash J, Bellefontaine N, Mazur D, Colledge WH, d'Anglemont de Tassigny X, et al. Kisspeptin-GPR54 signaling in mouse NO-synthesizing neurons participates in the hypothalamic control of ovulation. J Neurosci. 2012 Jan;32(3):932-45.

76 Clasadonte J, Poulain P, Beauvillain JC, Prevot $\mathrm{V}$. Activation of neuronal nitric oxide release inhibits spontaneous firing in adult gonadotropin-releasing hormone neurons: a possible local synchronizing signal. Endocrinology. 2008 Feb;149(2):587-96.

77 Bellefontaine N, Chachlaki K, Parkash J, Vanacker C, Colledge W, d'Anglemont de Tassigny $\mathrm{X}$, et al. Leptin-dependent neuronal NO signaling in the preoptic hypothalamus facilitates reproduction. J Clin Invest. 2014 Jun;124(6):2550-9.

78 Chachlaki K, Garthwaite J, Prevot V. The gentle art of saying NO: how nitric oxide gets things done in the hypothalamus. Nat Rev Endocrinol. 2017 Sep;13(9):521-35.

79 Prevot V, Dehouck B, Sharif A, Ciofi P, Giacobini P, Clasadonte J. The Versatile Tanycyte: A Hypothalamic Integrator of Reproduction and Energy Metabolism. Endocr Rev. 2018 Jun;39(3):333-68.
80 Tata B, Mimouni NE, Barbotin AL, Malone SA, Loyens A, Pigny P, et al. Elevated prenatal anti-Müllerian hormone reprograms the fetus and induces polycystic ovary syndrome in adulthood. Nat Med. 2018 Jun; 24(6):834-46.

81 Pankhurst MW, Chong YH, McLennan IS. Relative levels of the proprotein and cleavageactivated form of circulating human antiMüllerian hormone are sexually dimorphic and variable during the life cycle. Physiol Rep. 2016 May;4(9):e12783.

82 Herde MK, Geist K, Campbell RE, Herbison AE. Gonadotropin-releasing hormone neurons extend complex highly branched dendritic trees outside the blood-brain barrier. Endocrinology. 2011 Oct;152(10): 3832-41.

83 Schaeffer M, Langlet F, Lafont C, Molino F, Hodson DJ, Roux T, et al. Rapid sensing of circulating ghrelin by hypothalamic appetitemodifying neurons. Proc Natl Acad Sci USA. 2013 Jan;110(4):1512-7.

84 Ciofi P, Garret M, Lapirot O, Lafon P, Loyens A, Prévot V, et al. Brain-endocrine interactions: a microvascular route in the mediobasal hypothalamus. Endocrinology. 2009 Dec; 150(12):5509-19.

85 Bédécarrats GY, O’Neill FH, Norwitz ER, Kaiser UB, Teixeira J. Regulation of gonadotropin gene expression by Mullerian inhibiting substance. Proc Natl Acad Sci USA. 2003 Aug; 100(16):9348-53.

86 Garrel G, Denoyelle C, L'Hôte D, Picard JY, Teixeira J, Kaiser UB, et al. GnRH Transactivates Human AMH Receptor Gene via Egr1 and FOXO1 in Gonadotrope Cells. Neuroendocrinology. 2019;108(2):65-83.

87 Döhler KD, Wuttke W. Changes with age in levels of serum gonadotropins, prolactin and gonadal steroids in prepubertal male and female rats. Endocrinology. 1975 Oct;97(4): 898-907.

88 Dullaart J, Kent J, Ryle M. Serum gonadotrophin concentrations in infantile female mice. J Reprod Fertil. 1975 Apr;43(1):189-92.

89 Winter JS, Hughes IA, Reyes FI, Faiman C. Pituitary-gonadal relations in infancy: 2. Patterns of serum gonadal steroid concentrations in man from birth to two years of age. J Clin Endocrinol Metab. 1976 Apr;42(4):67986.

90 Chellakooty M, Schmidt IM, Haavisto AM, Boisen KA, Damgaard IN, Mau C, et al. Inhibin $\mathrm{A}$, inhibin $\mathrm{B}$, follicle-stimulating hormone, luteinizing hormone, estradiol, and sex hormone-binding globulin levels in 473 healthy infant girls. J Clin Endocrinol Metab. 2003 Aug;88(8):3515-20.

91 Prevot V. Puberty in mice and rats. In: Plant TM, Zeleznik J, editors. Knobil and Neill's physiology of reproduction. New-York: Elsevier, 2015. p. 1395-1439.

92 Kuiri-Hänninen T, Sankilampi U, Dunkel L. Activation of the hypothalamic-pituitary-gonadal axis in infancy: minipuberty. Horm Res Paediatr. 2014;82(2):73-80. 
93 Messina A, Langlet F, Chachlaki K, Roa J, Rasika S, Jouy N, et al. A microRNA switch regulates the rise in hypothalamic $\mathrm{GnRH}$ production before puberty. Nat Neurosci. 2016 Jun;19(6):835-44.

94 François CM, Petit F, Giton F, Gougeon A, Ravel C, Magre S, et al. A novel action of follicle-stimulating hormone in the ovary promotes estradiol production without inducing excessive follicular growth before puberty. Sci Rep. 2017 Apr;7(1):46222.

95 Azziz R, Woods KS, Reyna R, Key TJ, Knochenhauer ES, Yildiz BO. The prevalence and features of the polycystic ovary syndrome in an unselected population. J Clin Endocrinol Metab. 2004 Jun;89(6):2745-9.

96 Dumesic DA, Oberfield SE, Stener-Victorin E, Marshall JC, Laven JS, Legro RS. Scientific Statement on the Diagnostic Criteria, Epidemiology, Pathophysiology, and Molecular Genetics of Polycystic Ovary Syndrome. Endocr Rev. 2015 Oct;36(5):487525.

97 Escobar-Morreale HF. Polycystic ovary syndrome: definition, aetiology, diagnosis and treatment. Nat Rev Endocrinol. 2018 May; 14(5):270-84

98 Teede HJ, Misso ML, Costello MF, Dokras A, Laven J, Moran L, et al.; International PCOS Network. Recommendations from the international evidence-based guideline for the assessment and management of polycystic ovary syndrome. Hum Reprod. 2018 Sep;33(9):1602-18.

99 Rotterdam ESHRE/ASRM-Sponsored PCOS consensus workshop group: Revised 2003 consensus on diagnostic criteria and longterm health risks related to polycystic ovary syndrome (PCOS). Hum Reprod. 2004; 19(1):41-7.

100 Walters KA, Gilchrist RB, Ledger WL, Teede HJ, Handelsman DJ, Campbell RE. New perspectives on the pathogenesis of PCOS: neuroendocrine origins. Trends Endocrinol Metab. 2018 Dec;29(12):841-52.

101 Cook CL, Siow Y, Brenner AG, Fallat ME. Relationship between serum müllerian-inhibiting substance and other reproductive hormones in untreated women with polycystic ovary syndrome and normal women. Fertil Steril. 2002 Jan;77(1):141-6.

102 Pigny P, Jonard S, Robert Y, Dewailly D. Serum anti-Mullerian hormone as a surrogate for antral follicle count for definition of the polycystic ovary syndrome. J Clin Endocrinol Metab. 2006 Mar;91(3):941-5.
103 Pellatt L, Hanna L, Brincat M, Galea R, Brain $\mathrm{H}$, Whitehead S, et al. Granulosa cell production of anti-Müllerian hormone is increased in polycystic ovaries. J Clin Endocrinol Metab. 2007 Jan;92(1):240-5.

104 Pellatt L, Rice S, Mason HD. Anti-Müllerian hormone and polycystic ovary syndrome: a mountain too high? Reproduction. 2010 May;139(5):825-33.

105 Catteau-Jonard S, Bancquart J, Poncelet E Lefebvre-Maunoury C, Robin G, Dewailly D. Polycystic ovaries at ultrasound: normal variant or silent polycystic ovary syndrome? Ultrasound Obstet Gynecol. 2012 Aug;40(2): 223-9.

106 Abbott DH, Rayome BH, Dumesic DA, Lewis $\mathrm{KC}$, Edwards AK, Wallen $\mathrm{K}$, et al. Clustering of PCOS-like traits in naturally hyperandrogenic female rhesus monkeys. Hum Reprod. 2017 Apr;32(4):923-36.

107 Catteau-Jonard S, Dewailly D. Anti-Mullerian hormone and polycystic ovary syndrome. Gynécol Obstét Fertil. 2011 Sep;39(9): 514-7.

108 Laven JS, Mulders AG, Visser JA, Themmen AP, De Jong FH, Fauser BC. Anti-Müllerian hormone serum concentrations in normoovulatory and anovulatory women of reproductive age. J Clin Endocrinol Metab. 2004 Jan;89(1):318-23.

109 Catteau-Jonard S, Pigny P, Reyss AC, Decanter C, Poncelet E, Dewailly D. Changes in serum anti-mullerian hormone level during low-dose recombinant follicular-stimulating hormone therapy for anovulation in polycystic ovary syndrome. J Clin Endocrinol Metab. 2007 Nov;92(11):4138-43.

110 Taieb J, Grynberg M, Pierre A, Arouche N, Massart P, Belville C, et al. FSH and its second messenger cAMP stimulate the transcription of human anti-Müllerian hormone in cultured granulosa cells. Mol Endocrinol. 2011 Apr;25(4):645-55.

111 Huang CC, Tien YJ, Chen MJ, Chen CH, Ho HN, Yang YS. Symptom patterns and phenotypic subgrouping of women with polycystic ovary syndrome: association between endocrine characteristics and metabolic aberrations. Hum Reprod. 2015 Apr;30(4): 937-46.

112 Burt Solorzano CM, Beller JP, Abshire MY, Collins JS, McCartney CR, Marshall JC. Neuroendocrine dysfunction in polycystic ovary syndrome. Steroids. 2012 Mar;77(4): $332-7$
113 Goodarzi MO, Dumesic DA, Chazenbalk G Azziz R. Polycystic ovary syndrome: etiology, pathogenesis and diagnosis. Nat Rev Endocrinol. 2011 Apr;7(4):219-31.

114 Ehrmann DA. Polycystic ovary syndrome. N Engl J Med. 2005 Mar;352(12):1223-36.

115 McAllister JM, Legro RS, Modi BP, Strauss JF 3rd. Functional genomics of PCOS: from GWAS to molecular mechanisms. Trends Endocrinol Metab. 2015 Mar;26(3):118-24.

116 Georgopoulos NA, Karagiannidou E, Koika V, Roupas ND, Armeni A, Marioli D, et al. Increased frequency of the anti-mullerianinhibiting hormone receptor 2 (AMHR2) $482 \mathrm{~A}[\{\mathrm{GT}\}] \mathrm{G}$ polymorphism in women with polycystic ovary syndrome: relationship to luteinizing hormone levels. J Clin Endocrinol Metab. 2013 Nov;98(11):E1866-70.

117 Gorsic LK, Kosova G, Werstein B, Sisk R, Legro RS, Hayes MG, et al. Pathogenic AntiMüllerian Hormone Variants in Polycystic Ovary Syndrome. J Clin Endocrinol Metab. 2017 Aug;102(8):2862-72.

118 Gorsic LK, Dapas M, Legro RS, Hayes MG Urbanek M. Functional genetic variation in the anti-müllerian hormone pathway in women with polycystic ovary syndrome. J Clin Endocrinol Metab. 2019 Feb;104:2855-74.

119 Azziz R, Carmina E, Chen Z, Dunaif A, Laven JS, Legro RS, et al. Polycystic ovary syndrome. Nat Rev Dis Primers. 2016 Aug; 2:16057.

120 Sir-Petermann T, Maliqueo M, Codner E, Echiburú B, Crisosto N, Pérez V, et al. Early metabolic derangements in daughters of women with polycystic ovary syndrome. J Clin Endocrinol Metab. 2007 Dec;92(12): 4637-42.

121 Piltonen TT, Giacobini P, Edvinsson A Hustad S, Lager S, Morin-Papunen L, et al. Circulating antimüllerian hormone and steroid hormone levels remain high in pregnant women with polycystic ovary syndrome at term. Fertil Steril. 2019 Mar; 111(3):588-596.e1.

122 Maliqueo M, Lara HE, Sánchez F, Echiburú B, Crisosto N, Sir-Petermann T. Placental steroidogenesis in pregnant women with polycystic ovary syndrome. Eur J Obstet Gynecol Reprod Biol. 2013 Feb;166(2):151-5.

123 Sir-Petermann T, Maliqueo M, Angel B, Lara HE, Pérez-Bravo F, Recabarren SE. Maternal serum androgens in pregnant women with polycystic ovarian syndrome: possible implications in prenatal androgenization. Hum Reprod. 2002 Oct;17(10):2573-9.
Emerging Roles of AMH in

Hypothalamic-Pituitary Function
Neuroendocrinology 2019;109:218-229

DOI: $10.1159 / 000500689$ 